\title{
Optikai iparban termelődő szürkevíz minőségi és mennyiségi vizsgálata, javaslattétel kezelési technológiára
} Qualitative and quantitative analysis of optical industry produced grey water, proposal for treatment technology

\author{
${ }^{1}$ L. UngVÁRI, ${ }^{2}$ A. ÜVEgES KECZÁnNÉ \\ 1Debreceni Egyetem, zaleilah6@gmail.com \\ 2Debreceni Egyetem, auveges@eng.unideb.hu
}

\begin{abstract}
Absztrakt. Kutatásunk során a Carl Zeiss Vision Hungary Kft. mosodai szürkevizét vizsgáltuk. Kutatásunk célja, hogy az optikai iparban termelődő szürkevíz minőségi és mennyiségi paramétereiről átfogó képet kapjunk. A minőségi paraméterekre nézve további célunk volt, hogy vizsgáljuk, szükségszerü-e elszeparáltan gyüjteni az optikai iparban termelődő különböző eredetú szürkevizet. Ezt követően pedig olyan kezelési technológia kidolgozását terveztük, amely szürkevíz kezelés szempontjából gazdaságilag is értékes lenne a cég számára. Vizsgálatai eredményeink alátámasztják, hogy nem szükségszerű elszeparáltan gyüjteni a mosógépekből illetve a takarítógépekből származó szürkevizet, hiszen azok hasonló mértékben terheltek szennyező anyagokkal. A szürkevíz tisztítási technológiák pénzügyi értékeléséhez két különböző elven müködő technológiát vettünk alapul (koaguláció-flokkuláció, és aerob biomembrán technológia). Beruházási és fenntartási költségek tekintetében is egyértelmúen az aerob biomembrán technológia megvalósítása bizonyult gazdaságosabbnak.
\end{abstract}

Abstract. Our research we investigated Carl Zeiss Vision Hungary Kft. grey water from laundry. Our research aims to provide the optical industry produced grey water quality and quantity parameters to obtain a comprehensive picture. The quality parameters for additional aim was to test, whether it is worth tut collect grey water produced in the optical industry to the place of origin. Subsequently, the development of a treatment technology that economically it would be valuable for the company. It has been observed that it is not necessary tut collect grey water from washing machines and cleaning machinery, since it is similar to the organic load them. It was based on a financial assessment of the grey water treatment technologies in two technologies: coagulation-flocculation and aerobic bio membran technology. Investment and maintenance costs in respect of the implementation of the aerobic clearly bio membran technology proved to be more economical. 


\section{Bevezetés}

Napjaink és a 21. század legnagyobb klímaváltozás általi negatív hatása az ivóvíz hiány, illetve a nem megfelelő minőségű ivóvíz lesz. A vízhiány nemcsak az emberre nézve érzékelteti hatását, hanem hozzájárul a biológiai diverzitás csökkenéséhez is világszerte [1]. Igen fontos tehát, hogy ivóvíz készleteink felhasználása során, kitüntetett figyelmet fordítsunk a jövőnkre és az élővilágra egyaránt. A világ számos pontján már ma sem kerül elegendő mennyiségű és kellő minőségű ivóvíz a fogyasztókhoz. A WHO adatai alapján évente csaknem 3,5 millió ember hal meg a víz által terjesztett betegségekben. Az ENSZ állításai szerint 2025-re 700 millióról 3 milliárdra emelkedhet azoknak a száma, akik nem megfelelő minőségű vizet fogyasztva élnek [2].

A vízigények a népesség számával gyorsan növekednek. Fontos, hogy olyan tevékenységekre, amelyhez nincs szükségünk ivóvíz minőségű vízre (WC öblítés, autómosás, öntözés), olyan forrásból származó vizeket használjunk, amelyek nem eredményeznek ismételt ivóvíz felhasználást [3]. Ennek kapcsán fontos a szürkevíz, amely egy ürüléktől mentes szennyvízforma [4]. A szürkevíz használatnak számos gazdasági és környezetvédelmi előnye lehet, azonban nem használható fel bármilyen célra. Fontos megemlíteni a szürkevízben előfordulható szennyezőanyagokat: patogén baktériumok, olajok, zsírok, tisztítószerek, szappanok, tápanyagok, sók, élelmiszer maradékok, apró bőrdarabok, hajdarabok. Ezen szennyezők miatt fontos, hogy tisztítási technológiát alkalmazzunk a szürkevíz újra használata előtt [5]. A szürkevíz kezelési technológiák széles köre ismert, valamint folyamatosan hoznak létre újabbnál újabb módszereket, esetlegesen kombinálnak össze meglévő módszereket is annak érdekében, hogy minél hatékonyabb tisztítási hatásfokot érjenek el. A szürkevíz tisztítását úgy kell megtervezni, illetve kivitelezni, hogy a kezelési költségek és a káros hatások minimálisak legyenek [6].

\section{Anyag és módszer}

Kutatómunkám a Carl Zeiss Vision Hungary Kft.-nél keletkező mosodai szürkevíz vizsgálatához kötődik. A vizsgált cégnél a gyüjtőaknában lévő víz eredetét nézve igen összetett, melynek két fő komponense a mosásból származó szürkevíz és az ipari takarítógépek használt vizei. Fontosnak tartottuk, hogy a kevert szürkevíz (akna vize) mellet külön vizsgáljuk a kizárólagosan csak a mosógépekből származó szürkevizet. Ez a kvalitatív analízis alapját képezte. A mennyiségi analízis elvégzéséhez egy a mosodában felszerelt vízmérő óra is segítette a minél pontosabb érték megadását.

Minden szürkevíz minta esetén mértem a pH-t, fajlagos elektromos vezetőképességet, redox potenciált, sótartalmat Multi Line P4 (WTW GmbH, Germany) mérőbőrönd segítségével. Emellett vizsgáltam a zavarosságot, oldott szerves széntartalmat (DOC), biológiai oxigénigényt (BOI5), illetve

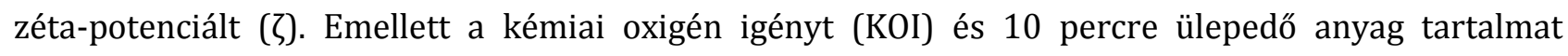
vizsgáltam.

A tisztítási technológia projektterv készítése kapcsán a kezdeti beruházási és fenntartási költségekkel számoltam. A beruházási költség nyilvánvalóan egy magasabb összeg, ez egyszeri kiadást jelent, mely tartalmazza a szükséges anyagi és humán erőforrások költségeit. A fenntartási költség folyamatosan 
jelentkezik, ez a kiépített technológiától is függ, mely értéke jóval alacsonyabb, mint a beruházási költség. Kétféle tisztítási technológiát vizsgáltam melyek tisztitási alapmúvelete egyik esetben a koagulációs-flokkulációs folyamatokon, másik esetben az aerob biomembránt alkalmazó biológiai tisztításon alapul.

\section{Eredmények értékelése}

A kvantitatív meghatározás kapcsán a mosodában elhelyezett vízóra segítségével határoztam meg a felhasznált ivóvíz mennyiségét. A fogyasztás havi szinten $20 \mathrm{~m}^{3}$-nek adódott, melyekből a mosógépek múködtetése $18 \mathrm{~m}^{3}$, míg a takarítógépek működése $2 \mathrm{~m}^{3}$ ivóvizet igényel. Az átlagos havi fogyasztás alapján a mosodában körülbelül 240 m³ mosóvíz keletkezik éves szinten.

A mosodában termelődő szürkevíz minőségi paramétereinek vizsgálatakor a cégnél a szennyvíz monitoring során is használt paramétereket vettem alapul. Kvalitatív analízist végeztem a gyűjtőakna vizének (kevert víz), illetve elkülönítve csak a mosásból származó szeparált szürkeviznek a minősítése céljából. A gyűjtőaknából származó kevert víz kémiai oxigén igénye csaknem 1500 mg/l (1. táblázat), a mosóvíz KOI értéke valamivel kevesebb $1250 \mathrm{mg} / \mathrm{l}$. A szürkevíz pH-ja mindkét esetben a lúgos tartományba esik, lúgos pH kedvezőtlen a cég számára, melynek oka, hogy a technológiában használatos egyéb anyagok, technológiai vizek, mosószerek szintén lúgos kémhatásúak. Kedvezőbb lenne egy semleges vagy savas tartományba eső víz, mely könnyen semleges irányba mozdíthatná el a kibocsátott szennyvíz pH-ját. A vezetőképességet tekintve a mosóvíz magasabb $(1980,0 \mu \mathrm{S} / \mathrm{cm})$ értékkel bír, mint a kevert víz (1391,9 S/cm). Ennek oka a takarítógépekből származó víz higító hatása lehet, hiszen ha a gyűjtőaknába kerül, akkor ez felhígitja a mosógépekből oda érkező mosószerekkel erősen terhelt vizet. A 10 percre ülepedő anyag tartalom szempontjából a kevert víz terheltebb, melyet valószínűleg pont a takarítógépekből ide kerülő szennyezők okoznak, amelyeket a gyártási területen gyűjt össze a takarítógép. A minőségi elemzés eredményei alapján elmondható, hogy nem indokolt külön gyűjteni a mosodában termelődő különböző eredetű szürkevizeket.

\begin{tabular}{|c|c|c|}
\hline Minta típusa & Paraméter & Átlag \\
\hline \multirow{4}{*}{$\begin{array}{c}\text { Kevert víz (gyújtőakna } \\
\text { vize) }\end{array}$} & KOI (mg/l) & 1496,6 \\
\hline & $\mathrm{pH}$ & 9,2 \\
\hline & Vezetőképesség ( $\mu \mathrm{S} / \mathrm{cm})$ & 1391,9 \\
\hline & Ülepedő anyag 10' (ml/l) & 21,4 \\
\hline \multirow{4}{*}{$\begin{array}{l}\text { Mosóvíz (csak } \\
\text { mosógépekből) }\end{array}$} & KOI (mg/l) & 1250,0 \\
\hline & $\mathrm{pH}$ & 8,9 \\
\hline & Vezetőképesség $(\mu \mathrm{S} / \mathrm{cm})$ & 1980,0 \\
\hline & Ülepedő anyag 10' (ml/l) & 14,0 \\
\hline
\end{tabular}

1. táblázat Szeparáltan gyüjtött mosóvíz és a kevert szürkevíz minőségi paraméterei

A projektterv készítése kapcsán két technológiát vettem figyelembe, amelyről átfogó pénzügyi számításokat és becsléseket végeztem, emellett vizsgáltam megvalósíthatósági lehetőségeiket. A két 
technológia: a szennyvíztisztításban is használatos koaguláció-flokkuláció elvén alapuló technológia, illetve az Akvawell Kft. által forgalmazott aerob biomembrán technológia.

A koaguláció-flokkuláció elvét alkalmazó tisztítási technológia többféle eszköz komplexeként építhető meg, amelyek méretezéséhez különböző gépészeti cégek ajánlatait vettem alapul, hogy az adott mennyiségű szürkevíz megfelelő minőségű tisztítása legyen megvalósítható. A technológia kivitelezése minimum három hónapot vesz igénybe, ebben az időintervallumban benne van a maximális tisztítási hatásfok elérésének ideje is, amelyet egy 1 hónapos próbaüzem előz meg. A vizsgált rendszer karbantartási igénye magas, hiszen több egybekapcsolt műtárgy és eszköz működéséről van szó. Egyszeri beruházási költsége hozzávetőlegesen 7472343 Ft + ÁFA, karbantartási költsége éves szinten körülbelül $550000 \mathrm{Ft}+$ ÁFA.

Az aerob biomembrán technológiát világszerte több helyen alkalmazzák, Magyarországon például az Akvawell Kft. foglalkozik a technológia kivitelezésével. A technológia biológiai tisztításon alapul, míg a koaguláció-flokkuláció kémiai tisztításnak felel meg a szennyvíztisztításban. Az aerob biommebrán és a hozzá tartozó reaktor helyigénye attól függ, mekkora teljesítményü berendezést szeretnénk beépíteni. Azonban a koaguláció-flokkulációnál bemutatott technológia műtárgyaival ellentétben ez kisebb helyigényű, így lehetőség van beltéri telepítésre. Ez a technológia 9 héten belül már teljes tisztítási hatásfokkal képes tisztítani a szürkevizet. Egyszeri beruházási költség ebben az esetben 5307910 Ft + ÁFA. Évente egyszeri karbantartás elegendő a rendszer kiváló működéséhez, amely költsége 100000 Ft + ÁFA-nál nem jelent többet.

\section{Következtetések}

A Carl Zeiss Vision Hungary Kft.-nél keletkező mosodai szürkevíz tekintetében megállapítottuk, hogy éves szinten minimum $240 \mathrm{~m}^{3}$ termelődik. Ez 100\%-ban újrahasznosítható lenne, melynek feltétele valamilyen szürkevíz tisztítási technológia beépítése. A szürkevíz eredetét tekintve takarítógépekből és mosógépekből származik, amelyek szeparált gyűjtése kvalitatív vizsgálataink alapján nem indokolt. A koaguláció-flokkuláció technológia egy bonyolultabb eljárás az aerob biomembránhoz képest. Beruházási költségeit tekintve magasabb értékekkel kell számolnunk, továbbá helyigénye nagyobb, valamint mütárgyainak többsége csak kültérre telepíthető. Ezzel szemben az aerob biomembrán technológia a mosoda részlegén az épületen belül is megfelelően elhelyezhető, így nem kell kialakítani külön helységet számára. Beruházási és fenntartási költségei is jóval alacsonyabbnak bizonyulnak a koaguláció-flokkuláció technológiájánál. A Carl Zeiss Vision Hungary Kft. részére az aerob biomembrán rendszer kivitelezése ajánlott, mely kiépítésével jelentős mértékű ivóvíz felhasználás csökkenés érhető el.

\section{Hivatkozások}

[1] Kates, R.W., Travis, W.R., Wilbanks, T.J., Transformational adaptation when incremental adaptations to climate change are insufficient. Proc. Natl. Acad. Sci. 109 (19), (2012) pp.7156-7161.

[2] ENSZ, Human Development Report, 2006. 
[3] Sarah E. Null, Liana Prudencio: Climate change effects on water allocations with season dependent water rights, Science of the Total Environment 571 (2016) pp. 943-954.

[4] Stefania Paris, Celine Schlapp: Greywater recycling in Vietnam - Application of the HUBER MBR process, Desalination 250 (2010) pp.1027-1030.

[5] Gideon Oron, Mike Adel, Vered Agmon, Eran Friedler, Rami Halperin, Ehud Leshem, Daniel Weinberg: Greywater use in Israel and worldwide: Standards and prospects. water research 58 (2014) pp. 92-101.

[6] C. Diaper, A. Dixon, D. Butler, A. Fewkes, S.A. Parsons, T. Stephenson, M. Strathern and J. Strutt, Water Sci. Tech., 43 (10) (2001) pp. 83-90. 